This item was submitted to Loughborough's Research Repository by the author.

Items in Figshare are protected by copyright, with all rights reserved, unless otherwise indicated.

\title{
A liquid/liquid two phase system as an economic alternative for the large- scale expansion of bone marrow-derived human mesenchymal stem/stromal cells (hMSCs)
}

\section{PLEASE CITE THE PUBLISHED VERSION}

https://doi.org/10.1016/j.jbiotec.2017.06.694

\section{PUBLISHER}

(C) Elsevier

\section{VERSION}

AM (Accepted Manuscript)

\section{PUBLISHER STATEMENT}

This work is made available according to the conditions of the Creative Commons Attribution-NonCommercialNoDerivatives 4.0 International (CC BY-NC-ND 4.0) licence. Full details of this licence are available at: https://creativecommons.org/licenses/by-nc-nd/4.0/

\section{LICENCE}

CC BY-NC-ND 4.0

\section{REPOSITORY RECORD}

Hanga, Mariana P., Alvin W. Nienow, Karen Coopman, and Christopher J. Hewitt. 2017. "A Liquid/liquid Two Phase System as an Economic Alternative for the Large-scale Expansion of Bone Marrow-derived Human Mesenchymal Stem/stromal Cells (hmscs)". figshare. https://hdl.handle.net/2134/27817. 
Conference Abstract: European Biotechnology Congress 2017

A liquid/liquid two phase system as an economic alternative for the large-scale expansion of bone marrow-derived human mesenchymal stem/stromal cells (hMSCs)

Petronela Hanga 1, Alvin W. Nienow 2, Karen Coopman 3, Christopher J. Hewitt 11Aston University, Birmingham, UK2University of Birmingham, Birmingham, UK3Loughborough University, Loughborough, UK

The traditional in vitro large scale culture systems for human mesenchymal stem cells (hMSCs) typically require the use of substrates such as microcarriers. While cell attachment to such substrates is advantageous for large scale expansion, cell harvest from the same substrates is at the moment one of the most important challenges that is hindering the faster development of cellbased therapies. Here, we proposed and investigated a liquid/liquid two phase system for the expansion and non-enzymatic recovery of viable and functional hMSCs, with potential to be employed at large scales. The proposed system makes use of a perfluorocarbon that forms two phase systems when mixed with cell culture medium, allowing for the formation of liquid droplets that act as 'liquid microcarriers' for cell expansion. hMSCs successfully attached and proliferated and post-expansion, retained their multipotency. Cell harvesting was achieved non-enzymatically in two steps, by firstly inducing droplet coalescence, then aspirating the interface and resulted in the recovery of cells with intact membrane proteins. Additionally, this system is cost-effective when employed at larger scales as a result of the perfluorocarbon recoverability and recyclability. No significant difference was found in cell growth in the systems made with either fresh or recycled perfluorocarbon. 